This PDF is a selection from a published volume from the National Bureau of Economic Research

Volume Title: Preventing Currency Crises in Emerging Markets

Volume Author/Editor: Sebastian Edwards and Jeffrey A.

Frankel, editors

Volume Publisher: University of Chicago Press

Volume ISBN: 0-226-18494-3

Volume URL: http://www.nber.org/books/edwa02-2

Conference Date: January 2001

Publication Date: January 2002

Title: When Is U.S. Bank Lending to Emerging Markets Volatile?

Author: Linda S. Goldberg

URL: http://www.nber.org/chapters/c10636 


\title{
When Is U.S. Bank Lending to Emerging Markets Volatile?
}

\author{
Linda S. Goldberg
}

\subsection{Introduction}

Little solid evidence exists on the practices of industrialized country banks operating in emerging markets. Critics of the industrialized countries' banks argue that these agents are unstable lenders who undermine local financial markets. Supporters see the foreign banks as key sources of otherwise scarce capital, with broader positive spillovers on the stability and efficiency of local financial markets. Clearly, there is a need for careful analysis of the lending practices of industrialized country banks to foreign clients. Our goal in this paper is to make progress in this direction by examining the activities of individual U.S. banks with foreign exposures. This microdata approach facilitates a comparison of the lending behavior of these banks in the complete set of countries in which the banks have positions. By working with bank-level data, we can consider which types of U.S. banks (with size as a defining characteristic) are the more volatile lenders, in which regions the lending by these banks is most volatile, and whether lending to certain regions is volatile mainly because of higher volatility of the economic fundamentals of these regions.

The main data we use are from quarterly foreign exposure data filed by each U.S. bank (or bank holding company) and collected as a component

Linda S. Goldberg is a vice president of the Federal Reserve Bank of New York and a research associate of the National Bureau of Economic Research.

Comments by participants at the preconference held at the 2000 NBER Summer Institute, at the January 2001 conference held in Islamorada, Florida, and especially by Simon Johnson are gratefully acknowledged, as well as comments from Leon Taub. The views expressed in this paper are those of the author and do not necessarily reflect the position of the Federal Reserve Bank of New York or the Federal Reserve System. Glenda Oskar provided excellent research assistance. 
of the bank supervisory process. The Country Exposure Reports provide a by-country distribution of the foreign claims held by individual U.S. banks, ${ }^{1}$ revealing the extent of geographic concentration (and, to a lesser extent, the maturity and type of concentration) of the bank's international holdings. We match these data with bank call report information to achieve corresponding series on the quarterly assets of the same set of banks. Taken together, these data enable us to discuss the international portfolio allocations of individual U.S. banks and consider the evolution of U.S. bank claims abroad.

We pose a number of questions relevant for understanding the scope of U.S. bank activity in international markets. First, what are the characteristics of those U.S. banks that are international players? We describe the number of reporting banks, the average size of these banks, the scope of their international exposures, and the geographical diversification of their portfolios. Second, what drives changes in U.S. bank claims on particular countries or regions? We conduct an econometric analysis of the sensitivity of various international positions to a set of key macroeconomic fundamentals. In the same way that Peek and Rosengren $(1997,2000)$ showed that Japanese banks transmit shocks from Japan to the United States, we consider whether U.S. banks transmit U.S. business cycle fluctuations to their foreign borrowers. We also posit that U.S. bank international exposures may be closely tied to the performance of particular countries or regions. We examine these relationships, considering throughout whether there are observable differences in these sensitivities across U.S. banks differentiated by their size or across the industrialized or emerging-market partners of the U.S. banks.

Our main findings are the following:

- Over the past two decades, the U.S. banks engaged in international lending have become more diverse: There are now fewer banks overall, and these banks are more polarized in terms of their size and portfolio allocations.

- An increasing portion of reporting U.S. banks, particularly smaller banks, maintains an exclusive focus on Latin American markets. The lending by smaller banks, especially with respect to Latin American and Asian markets, has been more volatile than the lending by larger banks.

- Compared with smaller U.S. banks, larger banks maintain claims on a larger number of countries. About 60 percent of large bank exposure is in industrialized countries, with most of the remaining exposure evenly split between the emerging markets of Latin America and Asia.

- Looking across U.S. banks, their foreign claims are highly correlated

1. The use of the term "U.S. banks" in this paper generally includes U.S.-owned banks and U.S. subsidiaries of foreign banks. 
with U.S. gross domestic product (GDP) growth, but not with foreign demand conditions. The negative correlation between U.S. bank claims and U.S. GDP growth for industrialized country partners suggests that net claims on these areas contract when the U.S. economy is expanding. A similar result arises for claims on emerging Asia. By contrast, the positive correlation observed for claims on Latin American countries suggests that lending to Latin America expands as the U.S. economy grows.

- Foreign claims of U.S. banks are correlated with real U.S. interest rates but generally uncorrelated with foreign real interest rates. Tighter real lending conditions in the United States are associated with lower real claims on industrialized countries and higher claims on Latin American countries.

- Overall, U.S. banks have not been volatile lenders internationally. Even in periods of international financial crisis, we do not observe statistically significant or extensive retrenchments of the international claims of U.S. banks.

These findings have direct relevance for currency crisis prevention in emerging markets. First, although U.S. banks are active participants in international markets, relatively few of these banks have high shares of their assets located abroad. A large portion of U.S. international claims remains within industrialized countries, but certain regions - most particularly Latin America - are important lending destinations of U.S. banks. In recent years, some small U.S. banks have heavily concentrated claims on Latin American countries and high ratios of foreign claims to overall bank assets.

The sensitivity of foreign claims to the U.S. business cycle parallels the type of observations that have been made by Peek and Rosengren, wherein Japanese banks were conduits for transmission of Japanese shocks to U.S. markets. In our sample, these spillovers are statistically significant for Latin America but not consistently so for other emerging market regions. ${ }^{2}$ The positive correlation implies that lending to Latin American countries rises when the United States grows faster, even after controlling for the local GDP growth. Some of this expansion may be related to trade credit provision or investments in Latin America's exporting sectors.

Small countries often express the concern that the international lenderby conducting lending activities directly through foreign-owned branches or indirectly through cross-border exposures - will make the emergingmarket economies more sensitive to external fluctuations through the lending channels. Although we concur that there is evidence of international

2. In some specifications there is a significantly negative correlation between U.S. GDP growth and U.S. bank claims on Asian emerging markets. Goldberg and Klein (1998) reached similar conclusions for foreign direct investment patterns. 
transmission of cycles, some of this correlation would likely be evident even in the absence of a U.S. bank presence. More important is the observation that generally the U.S. lenders are relatively stable providers of credit. Especially important is the lack of correlation between U.S. bank claims on emerging markets and the real demand cycles of those markets. These findings reinforce the conclusions by Dages, Goldberg, and Kinney (2000) that foreign banks operating in emerging markets may play an important role in stabilizing overall lending. Since local banks are highly sensitive to local conditions, stable credit supplies from external lenders may reduce the lending and investment instability in emerging-market economies in times of emerging market financial and balance-of-payments crises. As argued by Palmer (2000), U.S. banks appear to take a long view of their positions in many industrialized and emerging market regions, and local claims are relatively stable as a result.

The remainder of this paper is divided into three sections. Section 4.2 discusses the data, the U.S. banks that are lending abroad, and their international exposures. Section 4.3 econometrically explores the volatility of the international claims of the U.S. banks. Section 4.4 provides concluding remarks related to currency crisis prevention and presents suggestions for further analysis of this rich data source.

\subsection{Reporting Banks and Their International Exposures}

The main data for our analysis are from Country Exposure Reports filed quarterly by individual banks. The Federal Financial Institutions Examinations Council (FFIEC) report no. $009^{3}$ must be filed by every U.S. chartered insured commercial bank in the fifty states of the United States, the District of Columbia, Puerto Rico, and U.S. territories and possessions, that meets both of the following criteria:

(1) It has at least one of the following: a branch in a foreign country; a majority-owned subsidiary in a foreign country; an Edge for Agreement subsidiary; a branch in Puerto Rico or in any U.S. territory or possession (except that a bank with its head office in Puerto Rico or any U.S. territory or possession need not report if it meets only this criterion); or an International Banking Facility (IBF); and

(2) It has, on a fully consolidated bank basis, total outstanding claims on residents of foreign countries exceeding \$30 million in aggregate.

3. The FFIEC is an umbrella organization that collects and warehouses data for the Federal Reserve, Office of the Comptroller of the Currency, and Federal Deposit Insurance Corporation. Much of the information collected via the FFIEC 009 is made public, aggregated over all reporting banks, via the Country Exposure Lending Survey (FFIEC Statistical Release E.16). Palmer (2000) provides a useful discussion of trends in the aggregated data, with specific emphasis on emerging markets. 
Average Number of Reporting Banks, Over Time and by Region

\begin{tabular}{lrcc}
\hline & $1984-89$ & $1990-95$ & $1996-2000$ \\
\hline Industrialized countries & 182 & 137 & 72 \\
Developing Europe & 77 & 37 & 30 \\
Latin America & 183 & 133 & 78 \\
Asia & 122 & 85 & 50 \\
Africa & 71 & 40 & 27 \\
Middle East & 97 & 78 & 44 \\
Total reporting banks & 192 & 152 & 90 \\
\hline
\end{tabular}

The reported data provide considerable detail on the U.S. bank claims on foreign countries, with itemization by individual country. Bank claims are fairly broadly defined, encompassing credit extended to foreign country banks, public entities, and other recipients including individuals and businesses. In addition to direct international flows, bank claims also include revaluation gains on interest rate, foreign exchange, equity, commodity, and other off-balance sheet contracts. The reporting institution is asked to break down the cross-border claims outstanding by type of borrower (banks, public sector entities, other) and by time remaining to maturity (one year and under, one to five years, and over five years). In other quarterly reports, banks also provide information on their total assets located both in the United States and abroad.

There are 200 possible foreign "countries" in which a bank can report an exposure each quarter. These include industrialized countries; countries within emerging Europe (encompassing a number of small countries and countries that were formerly part of the Soviet Union); thirty-five countries under the heading of Latin America; forty under the heading of Asia/Pacific and the Middle East; and fifty-four countries within Africa. Each bank is required to provide detailed information on exposure to a country only when that exposure exceeds 1 percent of the reporting institution's total assets or 20 percent of its total capital, whichever is less.

For the time period spanned by our data, 1984 through 2000:Q2, the number of U.S. reporting banks with foreign exposures changes dramatically (table 4.1). In the second half of the 1980s, an average of 192 banks reported foreign exposures. ${ }^{4}$ Almost all reporting banks maintained positions in Latin America and in (non-U.S.) industrialized countries. A smaller pro-

4. Our unbalance panel originally began with 317 banks. Thirty-five banks had only one year or less of nonzero total exposure data and were deleted from our data set. Those observations with zero total exposure at any date were deleted from our sample. There were some foreign banks in our sample whose asset information was not representative of their entire conglomerate. Because this created an inconsistency between the scope of exposure information and the scope of asset information, these banks, classified as Edge Acts Banks and New York State Article 12 corporations, and two other banks with unusual situations were eliminated from the sample. 
Table 4.2

Size of Reporting Banks: Total Assets (US\$ millions)

\begin{tabular}{lccc}
\hline & $1984-89$ & $1990-95$ & $1996-2000$ \\
\hline Total reporting banks & 178.8 & 235.1 & 446.2 \\
Quartile 1 & $(261.1)$ & $(309.1)$ & $(677.7)$ \\
& 15.3 & 12.2 & 7.5 \\
Quartile 2 & $(9.3)$ & $(11.3)$ & $(7.3)$ \\
& 46.5 & 67.2 & 101.9 \\
Quartile 3 & $(10.0)$ & $(20.1)$ & $(48.9)$ \\
Quartile 4 & 112.4 & 182.0 & 321.1 \\
& $(40.5)$ & $(49.0)$ & $(79.6)$ \\
& 541.0 & 680.1 & $1,353.2$ \\
& $(301.7)$ & $(317.9)$ & $(823.4)$
\end{tabular}

Note: Means, with standard deviations in parentheses. Banks are sorted into quartiles by asset size.

portion of banks is involved in developing Asia, with banks less frequently involved in Africa and developing Europe.

The average number of reporting banks declined sharply over the course of the 1990s, down to 152 in the first half and to 90 in the latter half of the 1990s. Much of this reduction is associated with the general tendency toward banking sector consolidation in the United States over this period. Additionally, in the late 1990s some banks opted to report exposures consolidated at a bank holding company level, further reducing the number of distinct reporting institutions.

The data also reveal large changes in the relative popularity of regions among the reporting banks; over time, a smaller share of reporting banks was present in each region of the world. For example, whereas 182 banks had positions in (non-U.S.) industrialized countries in the late 1980s, this number declined to 72 by the late 1990s. ${ }^{5}$ The number of U.S. banks active in Latin America declined to 78.

Alongside the sharp decline in the number of banks over the past two decades, we observe important changes over time in the size distribution of the reporting banks (table 4.2). Although the mean and median bank size basically doubled over the period from 1984 through mid-2000, the actual change in the size distribution of these banks was much greater. Sorting banks by quartiles based on their total assets, the average bank in the lowest quartile became considerably smaller, down from $\$ 15$ million to $\$ 7.5$ million in assets. In the next quartile of banks, the average size doubled since the mid-1980s, with the representative bank growing from $\$ 46$ million to $\$ 102$ million. The size variation within these quartiles of banks also grew considerably. The banks classified in the 3rd and especially the 4th quartile

5. Throughout the paper, when we refer to "industrialized countries" this means industrialized countries other than the United States. The list of countries is provided in table 4A.3. 
Table 4.3 Foreign Portfolio Shares of Reporting Banks

\begin{tabular}{lccc}
\hline & $1984-89$ & $1990-95$ & $1996-2000$ \\
\hline Unweighted average across banks & 1.6 & 1.7 & 1.9 \\
& $(4.8)$ & $(5.8)$ & $(6.9)$ \\
Quartile 1 & 2.8 & 4.1 & 5.4 \\
& $(6.8)$ & $(9.5)$ & $(12.1)$ \\
Quartile 2 & 1.3 & 0.8 & 0.7 \\
& $(3.8)$ & $(2.3)$ & $(2.3)$ \\
Quartile 3 & 1.0 & 0.9 & 0.7 \\
& $(3.4)$ & $(3.5)$ & $(2.7)$ \\
Quartile 4 & 1.1 & 1.1 & 0.8 \\
& $(4.4)$ & $(4.4)$ & $(3.7)$ \\
Weighted average across banks ${ }^{\mathrm{a}}$ & 1.2 & 1.1 & 0.8 \\
& Reporting Banks & with Exposure $>1 \%$ & \\
Unweighted average across banks & 5.7 & 6.8 & 8.2 \\
& $(8.6)$ & $(10.6)$ & $(13.0)$ \\
Quartile 1 & 7.6 & 10.3 & 13.1 \\
& $(11.5)$ & $(14.5)$ & $(17.8)$ \\
Quartile 2 & 4.7 & 6.7 & 8.7 \\
& $(6.5)$ & $(10.0)$ & $(14.0)$ \\
Quartile 3 & 4.7 & 4.1 & 5.3 \\
& $(5.7)$ & $(5.5)$ & $(7.4)$ \\
Quartile 4 & 5.8 & 6.1 & 5.6 \\
& $(9.1)$ & $(9.4)$ & $(8.3)$ \\
Weighted average across banks ${ }^{\mathrm{a}}$ & 5.9 & 6.0 & 5.7 \\
\hline
\end{tabular}

Note: Means, with standard deviations in parentheses. Foreign exposures as a percent of total bank assets. Banks are divided into quartiles based on parent assets.

${ }^{\text {a U}}$ Using total asset weights.

more clearly reflect the phenomenon of banking sector consolidation. The average 4th quartile reporting bank tripled in asset size, to more than $\$ 1$ billion in assets by the late 1990s, with numerous banks considerably larger. From both tables 4.1 and 4.2 we conclude that although the number of reporting banks has declined, the remaining banks have become considerably more diverse.

Beyond differences in size, there are also huge differences across individual banks in their foreign exposure, measured as the sum of cross-border exposure and local country claims, and expressed relative to total bank assets (table 4.3). ${ }^{6}$ The first five rows of table 4.3 provide the unweighted averages of foreign exposure shares across all bank observations and within every period. For all banks taken together (and unweighted by bank size) there has been a tendency toward increasing shares of foreign exposure in average U.S. bank portfolios. However, this result is driven by tendencies

6. Observations are included for every period in which a bank reports nonzero foreign exposure. 
among the smaller banks actively participating in international markets. These banks have increased their average foreign portfolio share from 2.8 to 5.4 percent of bank assets. By contrast, the larger banks maintain smaller foreign portfolio shares (at approximately 1 percent of bank assets) with the overall shares slightly declining over time. Even when portfolio shares of all banks are weighted by their respective asset positions at each date, the overall foreign portfolio share of U.S. banks reporting foreign exposures has declined over time, to under 1 percent of U.S. bank assets.

The low foreign exposure shares in the first section of table 4.3 make it tempting to conclude that international exposures pose very low degrees of foreign risk to the reporting banks. This conclusion is inappropriate. Risk analysis is more often conducted in relation to parent bank capital or equity and is generally not relative to the bank's overall asset position. ${ }^{7}$ If a bank's capital is 10 percent of assets, a foreign portfolio share of 5 percent would suggest that the ratio of foreign exposure to capital is 50 percent for that bank - suggesting that bank equity can be substantially threatened by adverse external conditions. Additionally, the low numbers of the first section of table 4.3 are the result of having many banks with low exposuresat less than 1 percent of assets - reported together with a lesser (but still substantial) number of banks with much higher foreign exposures.

The second section of table 4.3 provides average exposures for only those banks that have foreign exposures greater than 1 percent of assets, a restriction that reduces our sample to only 15 percent of those observations reported in the first section of the table. Observe that these banks can have quite large exposures, rising to 8.2 (5.7) as unweighted (weighted) averages for the late 1990s. The tendency toward increasing exposure over time for the average bank is especially due to the large increases in foreign exposure shares by the smaller and medium-sized banks in the sample. This sample of larger banks has maintained foreign portfolio shares on the order of 5-6 percent of assets for the full period covered by our data.

The form of these exposures has changed over time in terms of regional concentration and in terms of clientele (e.g., banks, public sector borrowers, or other private borrowers). The diversification structure across location and clientele is important for ultimately interpreting our analysis of lending volatility later in the paper. One hypothesis is that when U.S. bank positions are highly dispersed regionally, their lending may be more insulated from region-specific disturbances and less volatile, even to regions experiencing shocks. ${ }^{8}$

Table 4.4 considers the share of all reporting banks, regardless of size,

7. See Palmer (2000) and Bomfim and Nelson (1999) for related discussions of the appropriate measurement of risk.

8. Dages, Goldberg, and Kinney (2000) show that within Argentina and Mexico, loans by domestic privately owned banks are more volatile with respect to local conditions than are loans by foreign-owned banks. 
When Is U.S. Bank Lending to Emerging Markets Volatile?

Percent of All Reporting Banks Maintaining a Position Exclusively in One Region

\begin{tabular}{lccccccc}
\hline & $\begin{array}{c}\text { Exclusive } \\
\text { Position } \\
\text { in Any } \\
\text { Region }\end{array}$ & $\begin{array}{c}\text { Industrialized } \\
\text { Countries }\end{array}$ & Europe & $\begin{array}{c}\text { Latin } \\
\text { America }\end{array}$ & Asia & Africa & $\begin{array}{c}\text { Middle } \\
\text { East }\end{array}$ \\
\cline { 3 - 8 } & 9.1 & 3.0 & 0.0 & 5.8 & 0.1 & 0.0 & 0.1 \\
$1984-89$ & 13.6 & 4.9 & 0.0 & 6.7 & 0.8 & 0.4 & 0.5 \\
$1990-95$ & 21.5 & 4.0 & 0.0 & 12.7 & 2.8 & 0.5 & 1.7 \\
$1996-2000$ & & &
\end{tabular}

Note: Last five columns represent developing country regions.

that maintain claims exclusively in one foreign region. ${ }^{9}$ Only 4 percent of all bank observations correspond to an exclusive position in industrialized countries. In stark contrast, by the second half of the 1990s more than 12 percent of banks had foreign exposures exclusively concentrated in developing countries of the Western Hemisphere (e.g., Latin America). These Latin American markets are the main foreign focus of some small, specialized banks operating out of the United States.

Given that a bank maintains an exposure to a particular region, we also examined the likelihood that the same bank is diversified to other regions. Claims on Latin American countries are always likely to be part of a bank's portfolio, regardless of other regions in which a bank maintains positions (see appendix table 4A.1). Moreover, if a bank has a position in Latin America, with the rise in Latin American specialization we observe a parallel decline over time in the likelihood of that bank's also having positions in industrialized economies, Asia, and Africa. If any bank has a position in industrialized countries, there is a greater than 80 percent probability that the bank will also have positions in Latin America and a 60 percent probability that it will also have positions in Asia.

The recipients of U.S. banks' foreign exposure have also evolved over time and across regions (table 4.5). The last sixteen years are characterized by a declining (but still substantial) role of bank-to-bank lending, by a general decline in lending to public entities, and by the rise in lending to a broader group of nonbank private clientele.

Distinguishing across regions, we further observe that

- In industrialized countries, the substantial shift away from bank-tobank lending matches the rise in nonbank private lending. Public-sector borrowers have played relatively small roles, hovering at about 10 percent of the U.S. bank claims on these regions.

- The importance of public-sector borrowers declined substantially as a fraction of activity in Latin American exposures. The decline was from 
Recipient Shares in U.S. Bank Exposure, by Period and Region

\begin{tabular}{lccc}
\hline & Banks & Public & Other Private \\
\hline 1984-89 & 47.6 & 29.1 & 19.3 \\
Industrialized countries & 62.4 & 12.8 & 18.7 \\
Developing Europe & 36.1 & 52.1 & 10.2 \\
Latin America & 36.3 & 40.6 & 20.8 \\
Asia & 47.5 & 24.4 & 21.2 \\
Africa & 21.2 & 52.1 & 23.9 \\
Middle East & 45.6 & 29.3 & 22.9 \\
1990-95 & 46.6 & 21.4 & 26.6 \\
Industrialized countries & 57.9 & 9.9 & 24.1 \\
Developing Europe & 30.7 & 41.3 & 25.9 \\
Latin America & 37.5 & 24.1 & 35.3 \\
Asia & 54.2 & 11.8 & 23.3 \\
Africa & 22.6 & 45.3 & 27.3 \\
Middle East & 39.5 & 40.4 & 18.1 \\
1996-2000 & 44.2 & 15.0 & 34.7 \\
Industrialized countries & 49.0 & 10.8 & 32.6 \\
Developing Europe & 37.0 & 28.7 & 30.6 \\
Latin America & 42.4 & 10.1 & 43.9 \\
Asia & 53.0 & 4.6 & 27.7 \\
Africa & 29.7 & 32.0 & 29.8 \\
Middle East & 43.3 & 35.1 & 18.9 \\
\hline
\end{tabular}

Note: Percent of total exposure by bank.

about 40 percent of individual bank claims in the mid- to late 1980s to just above 10 percent by the late 1990s. In absolute terms, there has been a huge increase in U.S. bank private lending to Latin American companies, with a smaller decline in public borrowing.

- For developing Asia, although the role of public borrowers has decreased since the late 1980s, the shift toward direct lending to nonbank private clients has not been as pronounced as is observed in other regions.

Also of interest is the source of these claims, which may be generated by cross-border operations or by lending by U.S. branch or subsidiary operations already located in foreign markets (table 4.6). The ratio of cross-border claims to total bank claims is near 100 percent for almost all regions and almost all banks in the lower three quartiles of banks. Local lending activities are prevalent mainly among the larger banks. Averaging over banks in the 4th quartile (again, without weighting by bank size), the share of U.S. bank claims that are generated by local lending is 16 percent for industrialized countries, 24 percent for developing Asia, and 10 percent for Latin American countries.

As a final descriptive exercise before turning to the volatility of claims of section 4.3 , in table 4.7 we show the average importance of particular regions to the foreign exposures of the reporting banks. First, U.S. banks hold 
The Relative Importance of Cross-Border versus Local Lending, by Region and by Quartile: \% of Cross-Border Exposure

\begin{tabular}{|c|c|c|c|c|c|c|}
\hline & \multirow[b]{2}{*}{$\begin{array}{l}\text { Industrialized } \\
\text { Countries }\end{array}$} & \multicolumn{5}{|c|}{ Developing Country Regions } \\
\hline & & Europe & $\begin{array}{c}\text { Latin } \\
\text { America }\end{array}$ & Asia & Africa & $\begin{array}{c}\text { Middle } \\
\text { East }\end{array}$ \\
\hline \multicolumn{7}{|l|}{ 1984-89 } \\
\hline All reporting banks & 94.1 & 99.2 & 98.5 & 93.5 & 97.5 & 98.1 \\
\hline Quartile 1 & 99.9 & 99.9 & 100.0 & 99.7 & 100.0 & 100.0 \\
\hline Quartile 2 & 99.0 & 100.0 & 100.0 & 99.1 & 99.9 & 100.0 \\
\hline Quartile 3 & 95.9 & 100.0 & 99.0 & 97.5 & 99.5 & 100.0 \\
\hline Quartile 4 & 78.3 & 98.1 & 94.1 & 83.5 & 95.7 & 95.5 \\
\hline \multicolumn{7}{|l|}{$1990-95$} \\
\hline All reporting banks & 91.9 & 98.0 & 97.0 & 89.3 & 95.2 & 98.0 \\
\hline Quartile 1 & 99.7 & 100.0 & 99.9 & 99.1 & 100.0 & 100.0 \\
\hline Quartile 2 & 98.1 & 100.0 & 99.8 & 97.8 & 99.7 & 100.0 \\
\hline Quartile 3 & 92.5 & 99.9 & 96.4 & 95.1 & 100.0 & 100.0 \\
\hline Quartile 4 & 74.8 & 96.3 & 90.1 & 74.6 & 92.2 & 95.2 \\
\hline \multicolumn{7}{|l|}{ 1996-2000 } \\
\hline All reporting banks & 92.2 & 96.3 & 96.4 & 85.3 & 91.5 & 97.4 \\
\hline Quartile 1 & 100.0 & 100.0 & 99.8 & 96.7 & 100.0 & 100.0 \\
\hline Quartile 2 & 96.3 & 99.9 & 97.8 & 89.8 & 100.0 & 100.0 \\
\hline Quartile 3 & 91.6 & 98.8 & 96.6 & 91.5 & 100.0 & 100.0 \\
\hline Quartile 4 & 84.2 & 96.3 & 90.5 & 76.0 & 92.2 & 96.0 \\
\hline
\end{tabular}

Regional Total Exposure Shares, Over Time and by Bank Type

\begin{tabular}{ccccccc}
\hline & & \multicolumn{5}{c}{ Developing Country Regions } \\
\cline { 3 - 7 } & Industrialized & & Aatin & Middle \\
& Countries & Europe & America & Asia & Africa & East \\
\hline 1984-89 & & & & & & \\
All banks & 55.5 & 1.0 & 26.0 & 13.3 & 2.4 & 1.8 \\
Quartile 1 & 51.5 & 0.9 & 37.5 & 5.5 & 1.7 & 3.1 \\
Quartile 2 & 52.6 & 1.2 & 34.0 & 10.2 & 1.1 & 0.9 \\
Quartile 3 & 53.5 & 0.9 & 29.4 & 12.7 & 1.9 & 1.6 \\
Quartile 4 & 56.3 & 1.0 & 24.2 & 14.0 & 2.7 & 1.9 \\
199-95 & & & & & & \\
All banks & 58.4 & 0.9 & 21.7 & 16.5 & 1.3 & 1.3 \\
Quartile 1 & 57.1 & 1.1 & 34.7 & 3.0 & 1.8 & 2.4 \\
Quartile 2 & 53.5 & 0.3 & 29.0 & 16.0 & 0.4 & 0.8 \\
Quartile 3 & 56.4 & 0.7 & 30.1 & 11.1 & 0.7 & 1.0 \\
Quartile 4 & 59.2 & 1.0 & 19.1 & 18.0 & 1.4 & 1.4 \\
199-2000 & & & & & & \\
All banks & 57.5 & 1.9 & 22.6 & 15.6 & 1.2 & 1.2 \\
Quartile 1 & 20.9 & 1.6 & 70.9 & 2.1 & 1.0 & 3.6 \\
Quartile 2 & 48.4 & 0.3 & 32.1 & 17.8 & 0.4 & 1.0 \\
Quartile 3 & 50.1 & 1.1 & 33.9 & 12.7 & 0.9 & 1.4 \\
Quartile 4 & 60.3 & 2.2 & 18.7 & 16.4 & 1.4 & 1.0 \\
\hline
\end{tabular}

Note: Unweighted by bank size: share of region in a bank's total foreign exposure. 
very small portions of their foreign portfolios in the regions of developing Europe, Africa, and the Middle East. On average, each of these regions is on the order of 1-2 percent of the foreign portfolio, regardless of the size of the banks. Among the largest banks, developing Europe gained popularity (to 2.2 percent of portfolios) in the second half of the 1990s. Among the smallest banks, the Middle East is in some cases a higher portion of bank portfolio (at 3-4 percent).

Reinforcing our earlier observations, table 4.7 shows the importance of claims on the Latin American countries to the portfolios of both large and small banks. While small banks have had disproportionately large emphasis on Latin American claims (at 37 percent in 1984-89, compared with 24 percent for the banks in the largest quartile), the role of Latin American investments soared for the smaller banks over the second half of the 1990s. For 1st quartile banks, Latin American claims reached over 70 percent of overall foreign exposures by the end of the 1990s. Claims on industrialized countries have generally been 50-60 percent of the foreign exposures of U.S. banks and remain at these levels for those banks without a more exclusive Latin American focus.

\subsection{The Volatility of International Exposures of U.S. Banks}

Although the previous section has demonstrated that significant differences exist across banks and over time in the size and composition of U.S. bank foreign claims, it did not address the reasons for and timing of changes in these claims. We now turn to this more dynamic issue, asking whether fluctuations in claims are econometrically explained by changes in the fundamentals of the countries in which these banks have claims and by changes in the fundamentals of the United States.

To examine the fluctuations of bank claims on specific groups of countries, we divide banks by asset size categories and into the three time intervals (1984-89, 1990-95, 1996-2000). We consider three arbitrary size divisions. First, we define as smaller banks those with less than $\$ 50$ million in overall assets (all in real terms). Medium banks have assets of $\$ 50$ million to $\$ 250$ million, and larger banks have assets in excess of \$250 million. Banks are assigned to these categories for each period in which they are in operation. Thus, if a bank grows from $\$ 100$ million in assets in 1987 to $\$ 500$ million in 1997, that bank will first be considered a medium-sized entity, and later, after crossing the arbitrary size threshold, will be a larger bank for the purpose of our specification.

The econometric unraveling of this volatility is easily motivated by basic portfolio theory. In that spirit, we model a bank's exposure to a country as dependent on the real rate of returns on investments in that country $c$, which are assumed to be functions of local interest rates, $i_{t}^{c}$ and on real GDP growth rates, $\mathrm{GGDP}_{t}^{c}$. These foreign country fundamentals are assessed rel- 
ative to home market conditions, captured by U.S. real interest rates and U.S. real GDP growth. Thus, we express the (log) claims of bank $i$ into country $c$ at time $t, \operatorname{Exp}_{t}^{i c}$, as ${ }^{10}$

$$
\begin{aligned}
\operatorname{Exp}_{t}^{i c}= & a_{0}^{i}+a_{1}^{i} t+a_{2}^{r}+a_{2}^{r} t+b \cdot i_{t}^{c}+c \cdot i_{t}^{u s}+d \cdot \operatorname{GGDP}_{t}^{c} \\
& +e \cdot \operatorname{GDDP}_{t}^{u s} .
\end{aligned}
$$

The terms $a^{i}+a_{1}^{i} t$ allow for the possibility that some banks have higher average changes and higher trend changes in the foreign exposure of their claims, independent of the time series variables in our specification. The terms $a^{r}+a_{2}^{r} t$ allow for the possibility that, regardless of observable fundamentals, some regions are more popular destinations for investment across banks. This popularity is modeled as having mean and trend components.

In order to avoid estimation problems potentially arising from the unit root properties of GDP growth, real interest rate, and claim series, we first difference equation (1). With this differencing, the bank and regional constant terms drop out, and the bank and regional trend terms enter the resulting first-difference specification in levels.

$$
\begin{aligned}
\Delta \operatorname{Exp}_{t}^{i c}= & a_{1}^{i}+a_{2}^{r}+b \cdot \Delta i_{t}^{c}+c \cdot \Delta i_{t}^{u s}+d \cdot \Delta \operatorname{GGDP}_{t}^{c} \\
& +e \cdot \Delta \operatorname{GGDP}_{t}^{u s}
\end{aligned}
$$

Equation (2) is our basic testing specification, stating that the change in a U.S. bank claims on any country has the following: a bank-specific component common across all regions (which can represent a trend toward or against further internationalization of a bank's overall exposure level); a region-specific component (which can represent a trend change in the popularity of claims of particular regions); components correlated with changes in foreign country and in U.S. real interest rates; and components correlated with changes in GDP growth rates for the foreign country and for the United States.

Using this specification, we pose the following questions to the bank data on country exposures:

- Do banks adjust exposure to different regions in similar ways in response to fluctuations in the macroeconomic fundamentals of those regions? Empirically, this translates into tests for common $b$ and $d$ across regions.

- Is U.S. bank exposure to some regions relatively more sensitive to changes in U.S. interest rates and U.S. output performance? Empirically, this translates into tests for common $c$ and $e$ across countries.

10. We performed a parallel analysis using the share of country $c$ claims in the bank's portfolio (i.e., claims relative to bank assets), instead of merely examining the changes in the actual bank claims on country $c$. The few substantive differences in results are noted later in this section. 
- Are smaller banks generally more volatile lenders? Empirically, this would translate into systematic differences in estimated coefficients $b$, $c, d$, and $e$ across banks, divided by size.

To estimate the elasticities of country claims with respect to fundamentals, we gather country-specific data on real GDP and real interest rates. Although our country sample initially contains 200 countries in which U.S. banks may have claims, we trim the sample in a number of reasonable dimensions. First, most banks have held positions in a much smaller set of countries. Looking across all banks together, on average banks maintain exposures with respect to twenty to twenty-five countries. Again, the aggregates mask big differences across larger and smaller banks (appendix table 4A.2). The larger banks in our sample (in the 4th quartile) tend to be invested in many more countries, with the average across these banks at eighty-six countries in the late 1980s, declining to sixty-six countries in the late 1990s. Overall, compared with smaller and mid-sized banks, larger banks have a greater number of countries in which they maintain relatively smaller foreign exposures.

Moreover, there are some countries in which U.S. banks have little or no exposure. By deleting these countries, we eliminate 51 of the 180 countries for which banks individually could provide foreign exposure data. ${ }^{11}$ Additional countries are dropped from our sample due to the absence of adequate data on interest rates or GDP. ${ }^{12}$ Because more data are generally available on GDP than on interest rates by country, we run the regression specification in a number of ways to generate appropriate insights on GDP and interest rate elasticities, while maximizing the number of countries and interval of observations explored. We find that the regression results are robust to the slightly narrower data sample that includes country real interest rates as well as real GDP growth. Consequently we report only the fully specified regressions.

We also want to limit the downward bias on significance that could potentially arise from keeping in the sample the large number of banks with very small foreign portfolio shares. The large quantity of bank observations with foreign exposure shares well below 1 percent of bank assets indicates that a relatively small number of U.S. banks account for a large share of the

11. Among the 200 initial "country" choices for reporting are about 20 international organizations and regional aggregates. We delete these "country" observations immediately. For our econometrics, we reduce the sample of countries examined by eliminating countries where U.S. banks, in aggregate, have less than $\$ 10$ million of total exposure. With other data-related exclusions, we are left with 105 countries for the regression analysis.

12. We generally use lending rates (IFS 60P), "the lending rate to meet the short and medium term financing needs of the private sector, differentiated by credit worthiness of borrowers and objectives of financing" (IMF 2001). If this rate is unavailable for a country, we use deposit rates (IFS 60L) or treasury bill rates (IFS 60C). Appendix table 4A.3 details which countries are ultimately included in our empirical specifications, along with a categorization of which countries fall under the heading of Europe, Latin America, Asia, Africa, and other regions. 
Regression Analysis Using Full Panel of Banks and Branches, Unweighted

\begin{tabular}{lcccccc}
\hline & & \multicolumn{5}{c}{ Developing Countries } \\
\cline { 3 - 6 } & $\begin{array}{c}\text { Industrialized } \\
\text { Countries }\end{array}$ & Europe & America & Asia & Africa & Middle \\
& 0.026 & 0.000 & 0.000 & 0.043 & -0.019 & -0.001 \\
\hline$\Delta i_{t}^{c}$ & $(0.044)$ & $(0.001)$ & $(0.000)$ & $(0.031)$ & $(0.045)$ & $(0.003)$ \\
$\Delta i_{t}^{u s}$ & $-0.074^{* * *}$ & -0.020 & $0.042^{*}$ & $-0.098^{* *}$ & 0.017 & -0.102 \\
& $(0.015)$ & $(0.623)$ & $(0.021)$ & $(0.041)$ & $(0.155)$ & $(0.116)$ \\
$\Delta$ GGDP $_{t}^{c}$ & -0.001 & 0.000 & -0.001 & $-0.001^{* *}$ & 0.001 & 0.005 \\
& $(0.003)$ & $(0.000)$ & $(0.005)$ & $(0.001)$ & $(0.050)$ & $(0.024)$ \\
$\Delta$ GGDP $_{t}^{u s}$ & $-0.106^{* * *}$ & -0.134 & $0.063^{* *}$ & $-0.142^{* *}$ & 0.011 & -0.135 \\
& $(0.021)$ & $(0.312)$ & $(0.029)$ & $(0.056)$ & $(0.215)$ & $(0.158)$ \\
Adjusted $^{2}$ & 0.485 & & & & & \\
$N$ & 21,700 & & & & & \\
\hline
\end{tabular}

Note: Standard errors in parentheses. All regressions include regional fixed effects and bank fixed effects. Includes only bank observations with foreign exposure exceeding 1 percent of bank assets.

***Statistical significance at the 1 percent level.

**Statistical significance at the 5 percent level.

*Statistical significance at the 10 percent level.

overall bank foreign exposure. We trim the data sample to that used in the first section of table 4.3 by eliminating from the reported regressions all observations for which bank total foreign exposure is less than 1 percent of total bank assets.

\subsubsection{Results}

Regressions based on equation (2) demonstrate significant differences in the effects of fundamentals on bank claims on countries in different regions. In table 4.8 we include all bank observations. In table 4.9 we report the results of regressions that differentiate across banks on the basis of size. In the reported specifications, the results are unweighted. The interpretation is that the results describe what - on average - influences the claims of individual banks, irrespective of differences across banks in the relative size of their claims on countries. The results should not, therefore, be viewed as describing the evolution of total credit to specific countries or regions.

The first row of table 4.8 shows that, across all U.S. banks reporting foreign exposures, the claims on specific countries are on average relatively insensitive to fluctuations in the real interest rates of those countries. Moreover, the GDP growth rates of both industrialized and emerging-market economies do not generally influence the claims on these countries by the average reporting bank. ${ }^{13}$ The lack of significance of own-country GDP 


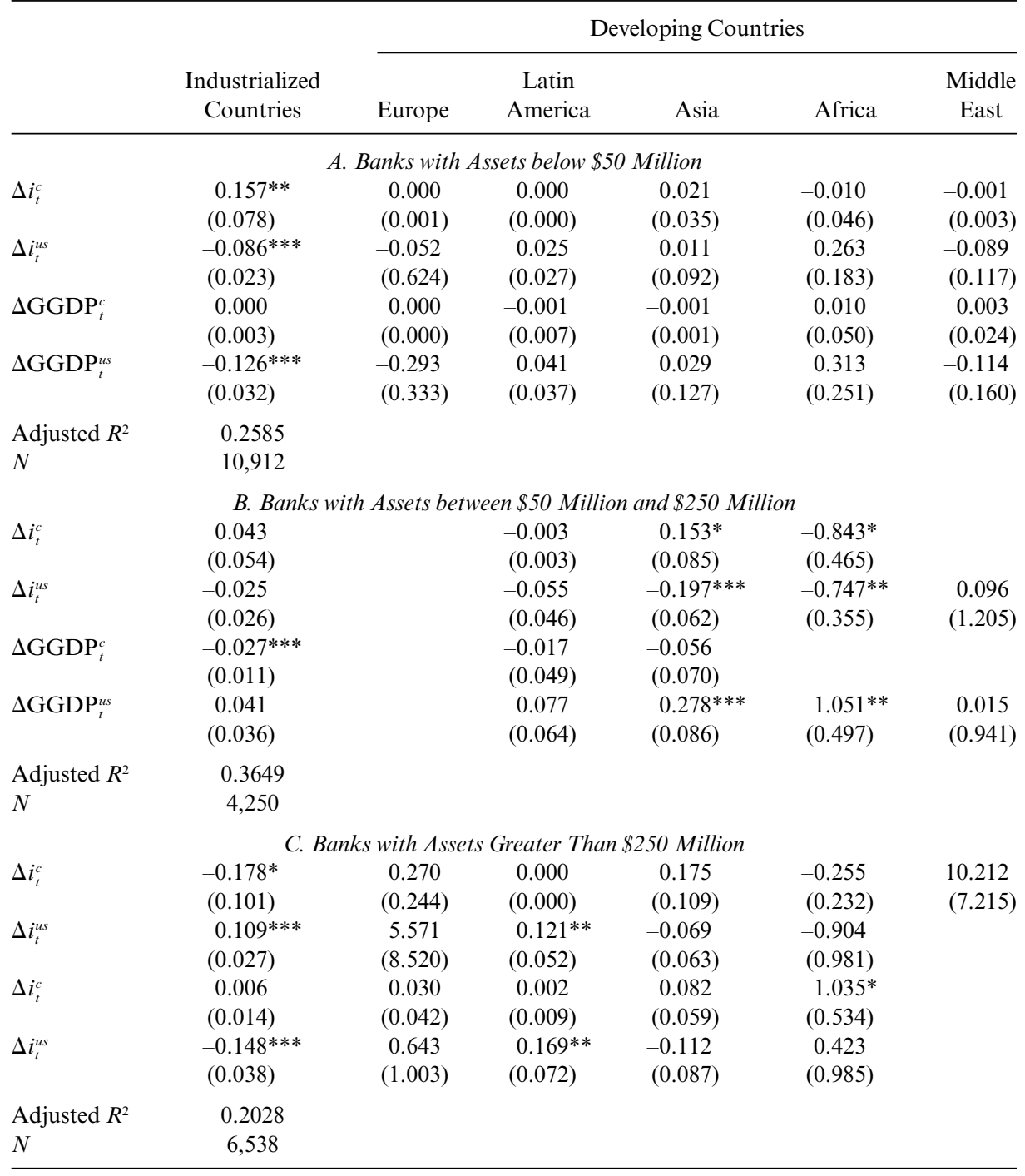

Notes: Standard errors in parentheses. All regressions include regional fixed effects and bank fixed effects. Table includes only bank observations with foreign exposure exceeding 1 percent of bank assets.

***Significant at the 1 percent level.

** Significant at the 5 percent level.

*Significant at the 10 percent level. 
growth and own-country interest rates for U.S. banks' claims on emerging markets is a consistent pattern observed across regression specifications.

More important determinants of U.S. bank claims abroad are the patterns in U.S. macroeconomic variables. Industrialized and Latin American country regions are the two regions in which these U.S. variables often have statistically significant effects. All else being equal, when interest rates rise in the United States, U.S. banks consistently reduce their claims on other industrialized countries, suggesting the possibility of substitution across markets. Likewise, higher U.S. GDP growth is consistently associated with reduced claims on other industrialized countries.

Higher U.S. GDP growth and interest rates have mixed effects on emerging markets, with some sensitivity to the regression specifications. For example, higher U.S. interest rates are associated with higher claims on Latin American countries in the unweighted regressions of table 4.8. Similar results arise in a claims-weighted version of this regression. For Asia, the sign of this relationship is negative for the average bank reported in table 4.8 but becomes positive in claims-weighted specifications. The direction of U.S. GDP growth on emerging-market claims is consistent across the unweighted and weighted regression specifications but differs across Latin America and Asia. Claims on Latin America expanded for a reporting U.S. bank when the United States grew faster, but on average claims on Asian countries contracted.

Next, we consider whether the broad description arising from table 4.8 is also pertinent when we divide banks according to their size but again compute regressions for the "average bank," that is, regressions unweighted by bank size or total claims. ${ }^{14} \mathrm{We}$ find that there are in fact observable differences across smaller and larger banks in the determinants of their claims on foreign countries. These differences are apparent through comparisons of parts A, B, and C of table 4.9.

First, for the banks in the smallest asset class category (part A), we observe differences in the role of fundamentals for claims on the (non-U.S.) industrialized countries versus those on emerging markets. While increases in industrialized country real interest rates are associated with larger claims on industrialized countries, claims on emerging markets are uncorrelated with real local lending rates. Claims on the (non-U.S.) industrialized countries fall when U.S. interest rates rise, consistent with some substitution between claims on the United States and other industrialized country borrowers. For the average small bank, none of the emerging-market macroeconomic fundamentals included in the regressions were statistically significant and qualitatively important determinants of changes in their claims

14. Bank size has been shown to be a relevant consideration in the U.S. lending markets: For example, as Hancock and Wilcox (1998) show, in response to declines in their own capital small banks shrank their loan portfolios considerably more than did large banks. 
on specific emerging markets. These patterns of results were robust to the inclusion of crisis period dummy variables in the regression specifications. ${ }^{15}$

For the larger banks shown in part $\mathrm{C}$, we again see the pattern of local country macroeconomic fundamentals being important mainly in the context of U.S. bank claims on industrialized countries. Within the emergingmarket groupings, U.S. bank claims on Latin American countries expand when the United States grows faster and when U.S. interest rates rise. ${ }^{16}$ For the other emerging-markets regions, claims on specific countries are not as tightly correlated with the macroeconomic fundamentals.

Finally, we generally observe larger point estimates on the coefficients in the regression specifications using observations for the larger U.S. banks. The differences in these point estimates are statistically significant in the context of claims on Latin American countries. Especially with respect to positions in emerging-market economies, the regressions suggest that trends in claims may be very significant for the smaller banks, as opposed to emerging market macroeconomic fundamentals. By contrast, larger bank positions have less important regional trends and appear to be more responsive to fundamentals. These patterns of results are robust to inclusion of crisis period dummy variables.

\subsection{Concluding Remarks}

Foreign credit to emerging markets is viewed as one means for deepening emerging capital markets and potentially reducing the severity of crises when they occur. One relevant issue is the stability of foreign bank claims on these markets and the source of volatility in these claims. U.S. banks generally seem to have been steady providers of credit to these markets in the face of fluctuations in emerging-market growth rates and interest rates. Because lending by banks within emerging markets is likely to be more sensitive to conditions in their home markets, these results suggest that the U.S. banks may contribute to more stable overall credit supplies in emerging markets.

On the other hand, the bank claims on emerging markets by large U.S. banks are sensitive to U.S. cyclical conditions. The countries end up with a more diversified supply of credit, but claims on emerging markets could fluctuate with conditions in foreign markets. The patterns of exposure of

15. We considered five distinct crisis dates: Latin American debt crisis (1984:1-1985:1); ERM crisis (1992:3-1993:1); Tequila crisis (1994:4-1995:1); Asia crisis (1997:3-1997:4); and Russian default (1998:3-1998:4). We entered these five period dummies into the regression specification of equation (2), permitting the effects to differ across the countries of the six regions in which U.S. banks have positions.

16. For claims on Latin America, there are qualitative differences between these results and those generated using U.S. bank portfolio allocations. The alternative approach shows that claims on Latin American countries, when measured relative to the overall assets of the specific banks, fall - not rise - significantly as U.S. GDP growth and real interest rates increase. 
small U.S. banks may be driven more by trends, while the exposures of larger U.S. banks may be driven more by changes in market fundamentals. There is little evidence of systematic differences in the behavior of U.S. bank claims across periods associated with international financial crises.

\section{Appendix}

U.S. Bank Conditional Exposures by Region

\begin{tabular}{lcccccc}
\hline & $\begin{array}{c}\text { Industrialized } \\
\text { Countries }\end{array}$ & $\begin{array}{c}\text { Developing } \\
\text { Europe }\end{array}$ & $\begin{array}{c}\text { Latin } \\
\text { America }\end{array}$ & Asia & Africa & $\begin{array}{c}\text { Middle } \\
\text { East }\end{array}$ \\
\hline 1984-89 & & & & & & \\
$\quad$ Industrialized countries & 1.00 & 0.40 & 0.94 & 0.64 & 0.38 & 0.38 \\
$\quad$ Developing Europe & 0.98 & 1.00 & 0.99 & 0.86 & 0.74 & 0.78 \\
Latin America & 0.92 & 0.39 & 1.00 & 0.61 & 0.37 & 0.49 \\
Asia & 0.99 & 0.54 & 0.98 & 1.00 & 0.54 & 0.61 \\
Africa & 1.00 & 0.78 & 0.99 & 0.91 & 1.00 & 0.73 \\
Middle East & 0.97 & 0.62 & 0.98 & 0.78 & 0.55 & 1.00 \\
1990-95 & & & & & & \\
Industrialized countries & 1.00 & 0.25 & 0.85 & 0.57 & 0.27 & 0.27 \\
Developing Europe & 0.98 & 1.00 & 0.98 & 0.80 & 0.68 & 0.83 \\
Latin America & 0.86 & 0.25 & 1.00 & 0.53 & 0.27 & 0.51 \\
Asia & 0.96 & 0.34 & 0.89 & 1.00 & 0.36 & 0.58 \\
Africa & 0.97 & 0.61 & 0.96 & 0.77 & 1.00 & 0.79 \\
Middle East & 0.90 & 0.38 & 0.91 & 0.62 & 0.40 & 1.00 \\
1996-2000 & & & & & & \\
Industrialized countries & 1.00 & 0.36 & 0.89 & 0.62 & 0.34 & 0.34 \\
Developing Europe & 0.96 & 1.00 & 0.96 & 0.81 & 0.63 & 0.82 \\
Latin America & 0.78 & 0.32 & 1.00 & 0.53 & 0.31 & 0.52 \\
Asia & 0.92 & 0.45 & 0.89 & 1.00 & 0.46 & 0.60 \\
Africa & 0.95 & 0.66 & 0.98 & 0.86 & 1.00 & 0.86 \\
Middle East & 0.87 & 0.50 & 0.94 & 0.66 & 0.49 & 1.00 \\
\hline
\end{tabular}

Note: Conditional on activity in a region in the stub column, the row entries provide the probability of also having a position in the other regions.

Table 4A.2 Average Number of Countries in Which Banks Have Foreign Exposures

\begin{tabular}{lccc}
\hline & \multicolumn{3}{c}{ Exposures } \\
\cline { 2 - 4 } & $1984-89$ & $1990-95$ & $1996-2000$ \\
\hline All reporting banks & 27 & 20 & 21 \\
Quartile 1 & 14 & 12 & 13 \\
Quartile 2 & 24 & 14 & 15 \\
Quartile 3 & 35 & 33 & 35 \\
Quartile 4 & 86 & 76 & 66 \\
\hline
\end{tabular}

Note: Banks are divided into quartiles according to their asset size. 
Table 4A.3 Countries Included in Regression Analysis, Using IFS Classification

\begin{tabular}{|c|c|c|c|c|c|}
\hline \multirow[b]{2}{*}{$\begin{array}{l}\text { Industrialized } \\
\text { Countries }\end{array}$} & \multicolumn{5}{|c|}{ Developing Countries } \\
\hline & $\begin{array}{l}\text { Developing } \\
\text { Europe }\end{array}$ & $\begin{array}{c}\text { Western } \\
\text { Hemisphere } \\
\text { (Latin America) }\end{array}$ & $\begin{array}{l}\text { Asia and } \\
\text { Pacific }\end{array}$ & Africa & $\begin{array}{l}\text { Middle } \\
\text { East }\end{array}$ \\
\hline Australia & Bulgaria & Argentina & Bangladesh & Chad & Bahrain \\
\hline Austria & Croatia & Bahamas & China & Congo & Egypt \\
\hline Belgium & Cyprus & Barbados & Fiji & Côte d'Ivoire & Israel \\
\hline Canada & Czech & Belize & Hong Kong & Equatorial & Jordan \\
\hline Denmark & Republic & Bolivia & India & Guinea & Kuwait \\
\hline Finland & Estonia & Brazil & Indonesia & Gabon & Oman \\
\hline France & Hungary & Chile & Malaysia & Ghana & Saudi Arabia \\
\hline Germany & Kazakhstan & Colombia & Mongolia & Guinea- & \\
\hline Greece & Latvia & Costa Rica & Pakistan & Bissau & \\
\hline Iceland & Lithuania & Dominican & Papua New & Kenya & \\
\hline Ireland & Macedonia & Republic & Guinea & Mauritius & \\
\hline Italy & Poland & Ecuador & The & Morocco & \\
\hline Japan & Romania & El Salvador & Philippines & Niger & \\
\hline Luxembourg & Russia & Guatemala & Singapore & Nigeria & \\
\hline The & Slovakia & Guyana & South Korea & Senegal & \\
\hline Netherlands & Slovenia & Haiti & Sri Lanka & South Africa & \\
\hline New Zealand & Turkey & Honduras & Thailand & Tunisia & \\
\hline Norway & Ukraine & Jamaica & Vanuatu & Zambia & \\
\hline Portugal & & Mexico & & & \\
\hline Spain & & Nicaragua & & & \\
\hline Sweden & & Panama & & & \\
\hline Switzerland & & Paraguay & & & \\
\hline United & & Peru & & & \\
\hline Kingdom & & Suriname & & & \\
\hline & & Trinidad and & & & \\
\hline & & Tobago & & & \\
\hline & & Uruguay & & & \\
\hline & & Venezuela & & & \\
\hline
\end{tabular}

\section{References}

Bomfim, Antulio and William Nelson. 1999. Profits and balance sheet developments at U.S. commercial banks in 1998. Federal Reserve Bulletin 85 (June): 36995.

Dages, B. Gerard, Linda Goldberg, and Daniel Kinney. 2000. Foreign and domestic bank participation in emerging markets: Lessons from Mexico and Argentina. Economic Policy Review 6 (3): 17-36.

Goldberg, Linda, and Michael Klein. 1998. Foreign direct investment, trade and real exchange rate linkages in developing countries. In Managing capital flows and exchange rates: Lessons from the Pacific Basin, ed. Reuven Glick, 73-100. Cambridge: Cambridge University Press.

Hancock, Diana, and James Wilcox. 1998. The credit crunch and the availability of credit to small business. Journal of Banking and Finance 22 (August): 983-1014. 
International Monetary Fund (IMF). 2001. International Financial Statistics 54 (12): 20.

Palmer, David. 2000. U.S. bank exposure to emerging-market countries during recent financial crises. Federal Reserve Bulletin 86 (2): 81-96.

Peek, Joe, and Eric Rosengren. 1997. The international transmission of financial shocks: The case of Japan. American Economic Review 87 (4): 495-505.

2000. Collateral damage: Effects of the Japanese bank crisis on real activity in the United States. American Economic Review 90 (1): 30-45.

\section{Comment Simon Johnson}

Linda S. Goldberg has provided us with fascinating information on three important questions. First, which U.S. banks lend outside the United States? Second, what is the pattern of this international lending, and how has this changed over time? Third, which parts of this bank lending are relatively volatile, and what drives this volatility? On all three issues, Goldberg both provides us with valuable new facts and points the way to further empirical and theoretical research.

Goldberg establishes that a great deal of cross-border lending is accounted for by relatively small banks, particularly those focused on Latin America. Very large banks also lend internationally but do so more through their own subsidiaries. Over time, fewer banks have been engaged in international lending, presumably as a result of bank consolidation. However, some of the smaller banks have increased their foreign exposure shares over time. There has also been an interesting increase in lending to the nonbank private sector.

Goldberg also shows that the portfolio share of foreign lending for U.S. banks is moved by U.S. gross domestic product (GDP) growth, not by U.S. interest rates (with interesting differences between the coefficients on lending to developed and emerging markets). This lending also does not appear to be sensitive to local GDP fluctuations or to movements in local real interest rates.

Goldberg has created a fascinating new data set that allows fresh insight into important questions. She has also covered a great deal of ground in terms of the preliminary analysis presented here. My suggestions are intended to indicate possible areas for further research (probably in the form of several separate papers).

My first question concerns exactly why U.S. banks lend overseas. Does this help them generate a superior return on equity, or does it represent

Simon Johnson is an associate professor of entrepreneurship at the Sloan School of Management, Massachusetts Institute of Technology, and a faculty research fellow of the National Bureau of Economic Research. 
some form of agency problem - or, perhaps, even a way to circumvent regulatory controls (e.g., perhaps it is easier to engage in connected lending to overseas affiliates)? Why is there so much more lending to Latin America by smaller banks than to Europe or Asia or anywhere else? Why does lending to Latin America have different characteristics, for example in terms of its sensitivity to U.S. GDP growth?

The volatility of U.S. bank lending could be usefully compared in more detail to that of local lending in various markets. Goldberg has already looked at this question in other work, but this new data set should allow further insight. Does it help or hurt stability when there is a large amount of lending by U.S. banks in a particular economy? Do U.S. banks pull out at the first sign of trouble, or are they able to take a longer view? Is there evidence that their presence is at all stabilizing, compared with the behavior of local banks? (See, e.g., the recent work of Rafael La Porta and Florencio Lopez-de-Silanes on Mexican banks after 1994.) The preliminary results presented here suggest that U.S. banks are not volatile lenders, but it would be helpful to look at this issue in more detail (and possibly to write the conclusive paper on this topic).

It would be useful to know more about the nature of overseas borrowers from U.S. banks. Some more work may be needed to combine this data with information on the reported exposure of publicly traded banks (and when they take loan loss provisions), but it will probably repay the effort. Are U.S. banks lending to exporters? Does this practice skim the cream off local banking relationships? Does this address the concerns about the constraints on financing development in weak legal systems measured by Rajan and Zingales (1998)? Does it help to keep the economy going even if local banks collapse? Quantifying these various effects would be very useful.

Looking at particular countries where there has been severe disruption of the banking system would be helpful (e.g., Indonesia from 1998.) To get at these issues, it might be worth starting the data set a little earlier (e.g., in the late 1970s or 1980) to compare the effect of several crises, for example those in 1982 and 1994-95. These data could also be related to controversies about the timing and causes of crises.

Does the nature of U.S. lending differ according to the institutional characteristics of the countries involved? For example, is lending to European Organization for Economic Cooperation and Development (OECD) countries different in a measurable way compared with lending to emerging markets or just poorer countries? Using the La Porta et al. (1998) classification of institutional systems would be useful here (e.g., as an alternative to the geographic classification in table 4.1).

Overall, Goldberg has written an extremely useful paper that provides important facts for researchers and regulators. It is my strong hope that Goldberg will use this information to write several more important papers. 


\section{References}

La Porta, Rafael, Florencio Lopez-de-Silanes, Andrei Shleifer, and Robert W. Vishny. 1998. Law and finance. Journal of Political Economy 106:1113-55.

Rajan, Raghuram, and Luigi Zingales. 1998. Financial dependence and growth. American Economic Review 88:559-86.

\section{Discussion Summary}

Charles W. Calomiris made three suggestions. He first offered the following explanation for the cyclicality of domestic and foreign bank lending in emerging markets. During a boom, domestic banks have access to cheap capital (from retained earnings) and thus can expand lending, which they sustain even in the initial contraction phase because they have a comparative advantage in identifying the quality of loans. During the period of deep recession, however, domestic banks cannot lend (because they have lost most of their capital), while foreign banks enter the market as a result of relaxed regulation on entry barriers. Thus, foreign lending is countercyclical. He suggested taking into account the business cycle of the recipient country when studying the bank-lending behavior.

His second suggestion was to isolate the relative capital cost effect from the portfolio opportunity effect by controlling for the cost of raising equity, as for example by using variables like underwriting costs. He also suggested to control for Spanish GDP cycle when studying Latin American countries.

Sebastian Edwards commented on the specific breakdown points of the period. The first subperiod of 1984-89 coincided with the Brady plan, at which time many banks exited the market; the end of the second subperiod of 1990-95 was around the time of Mexican crises, which also led many banks to go bankrupt.

He raised questions on the time series results of the paper because the sample period is very heterogeneous. For example, Argentina and Peru had hyperinflation, and Mexico underwent a series of crises; moreover, the banking sector in Latin America was very much regulated until 1989, and therefore the interest rates were not meaningful before that. He said that these structural changes during the sample period could be the reason for some of the strange findings in the paper (the dramatically different results for lending to Latin American and Europe). Lastly, Edwards suggested that one could do some more advanced studies on events such as financial integration by combining this data set and information on emerging markets' financial integration.

Rudi Dornbusch raised the question of whether the lending by small banks to Latin America is trade credit (which is safer and has extra tax ben- 
efits). He said that if this was the case, then one could run a gravity regression (before Andrew Rose does it) on lending of this particular sector. (Later in the discussion Nouriel Roubini conjectured that a large part of the lending of small U.S. banks in Latin America may reflect the money-laundering activities of small Miami banks instead of the provision of trade credits.)

Robert Dekle suggested that when looking at the transmission of shocks, one could include the nonperforming loan ratio and the Bank for International Settlements (BIS) capital ratio to capture the weakness of the banking sector.

Michael P. Dooley made the remark that a piece of the folklore is that European banks behave differently from the U.S. banks, so it would be interesting to include European banks as a control group and see whether U.S. banks are indeed different. He also suggested including variables such as the Federal Reserve Bank's ratings on emerging countries and the individual bank's loan loss experience in these countries in the regressions.

Joshua Aizenman suggested using exchange rates and measures of the probability of crises and country risk in the regressions.

Carlos A. Végh commented on the issue of volatility and cyclicality. First, what is the explanation for the fact that small foreign banks are more procyclical than big foreign banks? Second, he raised a question on the relative procyclicality of foreign banks compared to domestic banks. This is important for understanding whether foreign banks make cycles in these countries more or less pronounced. Third, he talked about the finding that U.S. banks' lending to emerging countries is highly correlated with the U.S. GDP. He said that when the United States is in a boom, interest rates go up, which typically implies that the GDP growth in emerging economies goes down, so U.S. lending is countercyclical to the cycles of emerging countries.

Jeffrey A. Frankel, in support of Vegh's last argument, cited a paper by Calvo, Leiderman, and Reinhart in which the authors argue that a reason for the large capital inflow to emerging countries in the early 1990s was the slow growth of Japan and United States.

John McHale commented on the weak sensitivity of U.S. lending to economic conditions in emerging countries. He asked how consistent this was with the turnaround of capital inflows to emerging markets during crises, and whether the behavior of U.S. banks was different from that of non-U.S. banks. Second, he commented on the finding that foreign lending is insensitive to local interest rates. As he pointed out, high interest rates can be attractive to foreign investors but may also signal bad economic conditions (a crisis). The finding of the weak effects might be the result of using pooled data, which suggests that one should control for crisis periods versus regular periods.

Roubini suggested that this rich data set could be used to test hypotheses related to theories about capital flight, and in particular to test whether cap- 
ital flights occur because of common creditor effects or contagion. This can be done by looking at what motivates banks' behavior during crises.

Linda S. Goldberg agreed that cycles are very important in studying foreign banks' lending behavior and indicated that she intended to incorporate that angle in subsequent work. This, she said, would contribute to a better understanding of the role of interest rates. She also said that it would be worthwhile to rethink the way regions were defined. An alternative could be to define country groups by their income levels. She agreed that the event study that Roubini suggested would be interesting and noted that one could also compare the U.S. banks' and Spanish banks' lending in Latin American countries. On the volatility of U.S. (or overall foreign) banks' lending relative to domestic bank lending, she cited one of her earlier studies. In that paper she showed that lending from both foreign and domestic private banks was procyclical (with respect to the local economy), but that the local lending was more procyclical because one of the sources of local banks' funding-local deposits - is more procyclical. 
